\title{
A philosophical-sociological diagnosis of youth subcultures in the context of social changes
}

\author{
Tadeusz Bąk - Maria Kardis - Michal Valco - Aydar M. Kalimullin - \\ Alexander A. Galushkin
}

DOI: 10.18355/XL.2019.12.02.14

\begin{abstract}
The article focuses on a diagnosis of youth subcultures in the context of public security. The authors, through their empirical research, exhibit favored, by subcultures, moral values, their processes of socialization as well as a particular type of responsibility showed by members of youth subcultures. The following subcultures were taken into consideration by the empirical research: the skinhead, the hip-hop, the chav, the punk, the metal, and the hippie. The research has confirmed a relationship between the quality of socialization displayed by youth subcultures and socializing factors such as family, school, peer group, and the mass media. It has been shown that the quality of social impact largely depends on responsibility attitudes of individual members of each subculture. Moreover, the research has revealed that a sense of responsibility is not an internalized value among the young, i.e., is not the one, which becomes a code of conduct or regulates human behavior. In that context, we have to mention that representatives of subcultures declared their clear sense of responsibility for their own families in the course of the undertaken research. Hence, it can be deduced that the family community is an important socializing factor which leaves an indelible mark on them.
\end{abstract}

Key words: youth subculture, public security, social change, behavior, socializing factors

\section{Introduction: Towards a diagnosis of youth subcultures in the context of social changes}

The literature of social sciences offers different definitions of youth subcultures. Experts on the topic have strived to explain the genesis and nature of this social phenomenon. "Affiliation to a subculture allows youth to express and fight for their ideals. At times, youth subcultures are perceived through their pathological demeanor, which overshadows a proper portrayal of subculture populations." (Bąk, 2009: 72-73) Youth subcultures are commonly believed to be a center of contestation. Forms of contestation might vary depending upon ideology and subculture. In contemporary societies, where a range of recipes strive to achieve "happiness and truth" are omnipresent. Many people, in particular during their adolescence time, detect an attractive form of expressing themselves and their desires through contestation and radicalism.

A phenomenon of subcultures should be perceived as a social educative and cultural problem. Alas, it is widely acknowledged that youth subcultures contravene our legal order. They partake in criminal offenses against life, health, and property. In such cases, their behavior demonstrates a desire to take it out, show off, to be brutal, which is a pure form of hooliganism and vandalism.

Subcultures encapsulate four structuring elements:

- $\quad$ A specific vocabulary;

- $\quad$ A specific emotional intonation;

- $\quad$ A specific behavior;

- $\quad$ A specific value system.

XLinguae, Volume 12 Issue 2, April 2019, ISSN 1337-8384, eISSN 2453-711X 
A sturdy bond between members of subculture exerts a strong influence on the unification of their scale of values. Hierarchy of values expresses features of a subculture and its uniqueness towards other subculture groups. They differ from one another on notions what is the most significant, significant or less essential in the life of an individual or a social group. (Bąk, 2009)

The number of members and sympathizers of a subculture is variable. Therefore, it is virtually impossible to provide any accurate quantitative data. Possibilities of a survey of subculture phenomena are interrelated with an in-depth analysis of internet materials and participation in various musical concerts performed by bands propagating ideals of subcultures. Besides a wide span of the age of subcultures' members hampers gathering data. (Bąk, 2008a: 9-33)

At present, phenomena of youth subcultures have to be considered from a perspective of globally social and cultural changes - there are many factors, put forward by social sciences, which have a significant influence: a socio-economic situation, uneven economic and professional chances and a lack of past-time fulfillment. Existence and development of subcultures depend on a politico-economic situation - if the latter is not stable and in crisis - subcultures develop swiftly such as in the case of the punk subculture. Moreover, it was scientifically acknowledged that upbringing in pathological and perturbed socially environment was an important factor in the development of subcultures. (Batura, 2008: 209)

\section{Personal Research}

A considerable intensification of activities by subculture groups has been observed in recent years all over Europe. Distinctively, aggressive behaviors by skinheads towards foreigners in Germany and other European Union (EU) member states often occur, thus it is essential to undertake research on youth subcultures in the EU and to show some of their characteristics. At this moment, the following question has to be formulated: what is the axiological character of subcultures' members, i.e., what value is attributed to the youth as far as their affiliation to subcultures is concerned. (Simmel, 1975) A catalog of values has been built based on categorization proposed by $\mathrm{H}$. Świda- Ziemba. This catalog enumerates the following values: intellectual; social; esthetical; allocentric; prestigious; materialistic; emotional; and perfectionist values. (Świda, 1999: 68)

Closer inspection to discern moral orientations of subcultures' members, their level and to what extent they differ from one another, was a separate issue from an axiological point of view. A research paradigm has led to the delineation between the following moral orientations: pro-societal, dignified, mutual and rigorous orientation (the latter is related to taboos). (Kiciński, 1983: 99)

In addition, the identification of specific values characterizing subcultures' members was a third research problem from the axiological point of view. This type of research has allowed, not only to discern an "official" ideology of a subculture but also to gain knowledge about axiological causes for affiliation to a subculture. In this case, there was no preconceived operationalization applied upon the research. Respondents were allowed to answer spontaneously, and their answers were attributed to the following categories of values: freedom, personality, socio-political values, hedonism, permissiveness (i.e., no norms).

Furthermore, the exploration of a socialization image of subcultures' members was an important issue for the research. A platform of socialization is related to a set of rules and regulations, which organize a life of particular groups, such as these linked to responsibility and tolerance (Bąk, 2008c: 24-25) - these attributes are addressed to wider social circles, nomen agentis and social institutions. Three socializing dimensions were used to analyze the socialization of subculture groups: a sense of responsibility, tolerance and personality paradigm. A discussion aiming at determining the personality paradigm underlies an idea to inspect socialization levels 
of subcultures' members - this trend was introduced by M. Ossowska (1992: 76). The author of "Podstawy nauki o moralności" enumerates the following attributes in the catalogue of the personality paradigm: aspiration for perfectionism; openness; internal discipline; tolerance; activism; civil courage; intellectual honesty; criticism; responsibility for the word; interest in public affairs; generosity; ability to cooperate; sense of responsibility for social collectiveness; chivalry; esthetical sensibility; and sense of humour. Among the attributes mentioned above, most attention was drawn to two personality paradigms, which were considered important by M. Ossowska and other authors, i.e., tolerance, and the sense of responsibility for social collectiveness. (Birnbacher, 1999; Bauman, 1992; Ostrowska, 1995)

At this moment, it is indispensable to mention, as S. Nowak suggests, that an emotional element is the most essential for the personality base. Therefore, questions posed to respondents concerned the emotional element (for example: "To what extent do you agree with the following opinions?", "Please mark if you agree with the following answers", "Which of the following behaviors are acceptable to an average citizen and which are not"). Nonetheless, other types of questions were also posed to respondents (for example: "Are you interested in socio-political affairs?", "If it depended on you, would you agree that...?"). It was assumed that respondents were evaluating themselves as far as the intensity of certain moral qualities were concerned. The choices made were oscillating between extremities: categorically yes or categorically no. Such a procedure allowed for a relative objectification of subjective marks of the respondents through the expression of open judgment about herself or himself.

An attempt to describe socio-demographic correlatives of particular youth subcultures such as the Punk subculture, the Metal subculture, the Skinhead subculture, the Hiphop/Chav and the Hippie was the next ingredient of the undertaken research. Thereby, an attempt was made to seize a differentiation of subcultures' image as well as factors, which condition the differentiation. A relation of a cause and a consequence was signaled in interpretations made in the research. The following types of sociodemographic backgrounds were taken into account: "affiliation to a social organisation" ( "affiliated", "non-affiliated"), "religious practices" (" I practice regularly", "I don't practice regularly", "I practice seldom", "I don't practice"); "attitude towards faith" ("strong believer", "believer", "indecisive but attached to religious faith", "indifferent/atheist"); "gender" ("female", "male"); "place of residence" ("village", "town to 100000 inhabitants", "town over 100000 inhabitants"), "father's education" ("basic"/"basic professional", "secondary education", "higher education"); "financial situation" ("very good", "rather good", "medium", "rather bad", "very bad").

In the context of the research mentioned above, the following questions were formulated:

- What are moral orientations of subcultures' members?

- Which are the most prevailing moral orientations among respondents?

- Which variables correlate with the proposed hierarchy of values and moral orientations?

- What values and ideals are attributed to which subculture?

- What is the level of socialization of subcultures' members?

- What is their preferred personality?

- Do they feel responsible for their social environment (family, local community, international community, national community, religious groups, schoolmates, Church community, state community, group of friends)? 
- What is the level of tolerance of subcultures' members (for asylum seekers, infected by AIDS, alcoholics, practitioners of an unknown religion, addicted to drugs, disabled, retarded mentally)?

- What are variables which determine a sense of responsibility and tolerance among subcultures' groups?

- What is, taking into account selected socio-demographic variables, the social background, differentiation of each subculture group?

The methodology of social research entails a general system of rules concerning a specific research activity, i.e., cognitive and practical operations, an order of their application, specific means and activities aiming at a particular research goal. In our survey, questionnaires such as inquiry forms and interviews were used - advocators and opponents of questionnaires agree that these forms of acquiring information are the most efficient. The anonymity of questionnaires allowed respondents to be more open and secured. In this case, a questionnaire - inquiry forms were used and helped conduct research individually and collectively, i.e., research can be applied upon a larger group of people.

A researcher does not need to contact respondents personally but can use a post or resort to others who will survey him/her. The questionnaire - inquiry form usually looks the same and answers are easily comparable and translated into synthetic results. A written questionnaire is the most popular form distributed to respondents. Possibility of fast acquisition of information is a major reason to have been chosen as the most efficient. All respondents answer the same questions, which are direct and apparent. The questionnaire- inquiry form has been justified due to:

- $\quad$ answers by respondents are honest

- $\quad$ they include clear and simple questions which do not cause doubts

- the questionnaire is not lengthy; thus it does not discourage respondents from providing answers.

The questionnaire constitutes a set of questions - respondents should be familiar with the content of questions and should possess sufficient knowledge about them in order to provide answers. The planning involving preparation of clear questions and multiple answers' choice is of key importance for the research process. It facilitates an analysis of the research results. (Sztabinski, 2000: 50-54)

The preparation of an instruction to fill the questionnaire for respondents is another important element of the research process. It includes information on how a surveyor should introduce himself/herself to respondents and how he should present the following data:

- $\quad$ generic sketch of the research;

- $\quad$ name of the institution that has undertaken the research;

- general information about the research purpose;

- $\quad$ respondents' answers will be analyzed scientifically and remain unknown to the public except for the researcher

- a request addressed to a respondent asking him/her to agree to participate in the research and answer to all questions the best to his knowledge.

Conditions in which respondents fill in questionnaires are decisive for a true value of research and receive a guarantee that obtained data will not be made public. A surveyor must take into account a potential necessity to offer explanations to respondents throughout the conduct of the questionnaire. The research is presented in the form of statistics which include a description and a potential conclusion. Characteristics of a researched collectiveness should embrace education, social status, financial status, etc. Due to its simplicity and economy of means, a method of the 
questionnaire is the most commonly applied research method despite its limitations and shortcomings.

A diagnostic survey concerns the research of a specially selected group which represent a population where a researched phenomenon is present. The research for this article was accomplished using this method of the diagnostic survey, the selfadministered questionnaire. The method encompasses information gathering about structural and functional subjects, changes occurring in social groups as well as gathering views in selected communities. A role of the surveyor is limited in the method mentioned above.

The research was undertaken in 2009 (May through October) and took into account a randomized trial performed among subcultures' members. Respondents participated in the trial of subcultures' members through a "snowball sampling" in pilot regions. The snowball sampling is a nonprobabilistic technique of sampling which is considered by some as randomized. This method is applied when finding representatives of a specific community such as homeless, migrant workers, illegal immigrants, homosexuals, subcultures' members is regarded most difficult. The method of snowball sampling allows to collect data about several members of populations with which they are familiar, the term "snowball sampling" refers to a process of accumulation of each person that refers to another person. Representativeness of samplings revealed by this method could be put in doubt for it is used mostly for explorative reasons. (Earl, 2004: 206-207)

A randomized multi-gradual choice is a method of randomizing teams of entities of lower degree originating from divisions of teams of higher degree. In the beginning, entities of the first randomized choice of the first degree are taken into account consisting of bigger teams of entities. Subsequently, entities are divided into smaller teams which are called entities of second randomized choice of the second degree. Further, these entities are divided into smaller teams called entities of the third randomized choice of the third degree. This division continues until the research covers basic levels (individuals). A scheme of randomized choice of two degrees is the most simple type of multi-gradual randomized choice. In the first degree, the research is based on an appropriate randomizing operator. In the second degree, based on a formation of specific randomizing operators fit for each group and out of these, a certain amount of elements is drawn (i.e., this is a stage of individual limitless randomization). (Mlynarski, 2000: 30)

Specifically, 120 respondents participated in the research. Questions concerned opinions and views of youth about selected social issues, moral issues, preferences about social life, personality, participation in social life, attitude towards values and social environment. The questionnaire of the research consisted of 39 open and closed questions.

The above-described method allowed to determine equal amounts of sampling for each of the researched subcultures' groups. Exceptions were made by the Hippie whose number was far smaller due to its small number as such, existing in our society and a lack of interest from the society. 
Table 1. Descriptive statistics - the breakdown of the probed sampling regarding "subculture"

\begin{tabular}{|l|l|l|l|}
\hline Subculture & & Percentage \\
\hline Important & Punk & & 21.2 \\
\cline { 2 - 4 } & Metal & & 21.5 \\
\cline { 2 - 4 } & Skinhead & 20.0 \\
\cline { 2 - 4 } & Chivs (Hip-Hop) & 23.6 \\
\cline { 2 - 4 } & Hippie & 13.7 \\
\hline Lack of data & Systematic lack of data & \\
\hline Total & & 100 \\
\hline
\end{tabular}

The biggest group, nearly a half $(43.5 \%)$ of the probed, constituted persons of a long "record" in a subculture. (4-6 years' affiliation). Every third respondent declared his/her affiliation for "3 years", every seventh respondent declared "7-9 years" of affiliation. Solely, every tenth probed person had "10 years and more" affiliation (see Table 2.) In this case, it can be assumed that the large majority of the probed group of respondents is a population of persons who acceded their subcultures in the current social situation. This approach allows creating predicators of subcultures which are entrenched in a contemporary social structure and to falsify the up-to-date hypothesis concerning genesis and activities of subcultures.

Table 2. Descriptive Statistics - the breakdown of the probed sampling regarding "period of affiliation to subcultures"

\begin{tabular}{|l|l|l|l|}
\hline Period of affiliation to subcultures & & Percentage \\
\hline Important & Up to 3 years & 28 \\
\cline { 2 - 4 } & Up to 4-6 years & 43.5 \\
\cline { 2 - 4 } & Up to 7-9 years & 16.8 \\
\cline { 2 - 4 } & Up to 10 and more years & 11.5 \\
\cline { 2 - 4 } & Total & 100 \\
\hline Lack of data & Systematic lack of data & \\
\hline
\end{tabular}

The probed population was not much differentiated in the context of a place of residence - received proportions come from a real demographic situation in regions. It was confirmed that variable of "age" correlate to the category of "subculture" due to, according to surveyors, having found subcultures' members mostly in regions where there are many schools and students rather than where there are not that many schools in scarcely populated areas. These data also correspond to statistics of the Police concerning subcultures as well as to views of subcultures' members who are largely dispersed in some areas. The data were obtained during individual and group interviews with those members.

Boys $(67.45 \%)$ constitute a large majority of the probed respondents. Solely every third respondent $(32.6 \%)$ were of another gender. The sampling was not able to determine with certainty that the breakdown in the context of a variable of gender could be proportional to the breakdown of that variable in the whole population of subcultures' members.

However, such a proportion of numbers correspond to declarations of subcultures' members as well as to social observations of researchers dealing with subcultures. 
Table 3. Descriptive Statistics - the breakdown of the probed sampling regarding "gender"

\begin{tabular}{|l|l|l|l|}
\hline Gender & & Percentage \\
\hline \multirow{3}{*}{ Important } & Female & & 32.6 \\
\cline { 2 - 4 } & Male & & 67.4 \\
\cline { 2 - 4 } & Total & & 100.0 \\
\hline Lack of data & Systematic lack of data & & \\
\hline
\end{tabular}

In terms of age, a group of adults to 25 years old was a dominant category (70.9\%), adolescent youth to 18 years old was the second category (23.2\%). If a person is more than 25 years old, a smaller chance he/she has to become a target of subcultures. The surveyors found only $5.9 \%$ older respondents that were more than 25 years old (see Table 4). This observation will play an essential role in the further analysis of current predictors of activities generating cultures of subcultures.

Table 4. Descriptive statistics - the breakdown regarding "age"

\begin{tabular}{|l|l|l|l|}
\hline Age & To 18 years old & Percentage \\
\hline \multirow{4}{*}{ Important } & 19-25 years old & 23.2 \\
\cline { 2 - 4 } & 26 years old and more & 70.9 \\
\cline { 2 - 4 } & Total & 5.9 \\
\hline Lack of data & Systematic lack of data & & \\
\hline
\end{tabular}

The implicit probe of sampling determined the breakdown of the probed group in the context of a variable independent on a "permanent place of residence. The majority of respondents came from large or medium-sized cities where population was the largest (21.000 to 500.000 inhabitants $-32.4 \%, 501.000$ and more inhabitants $-33.6 \%$ ), every seventh respondent came from villages and smaller cities to 20.000 inhabitants (village $-17.4 \%$, city to 20.000 inhabitants $-16.6 \%$ ) (see Table 5).

Table 5. Descriptive statistics - the breakdown regarding "permanent place of residence"

\begin{tabular}{|l|l|l|}
\hline Permanent place of residence & Percentage \\
\hline Important & Village & 17.4 \\
\cline { 2 - 3 } & City to 20 000 inhabitants & 16.6 \\
\cline { 2 - 3 } & $\begin{array}{l}\text { City from 21000 to 500 000 } \\
\text { inhabitants }\end{array}$ & 32.4 \\
\hline & $\begin{array}{l}\text { City more than 500 000 } \\
\text { inhabitants }\end{array}$ & 33.6 \\
\cline { 2 - 3 } & Total & 100.0 \\
\hline Lack of data & Systematic lack of data & \\
\hline
\end{tabular}

A breakdown in the context of "education" of respondents is similar to a breakdown of this variable in the whole population of Polish society. It can be again assumed that despite the use of a two-stage sampling method, the results were similar to those received while probing representatives of the Polish youth. The majority of respondents possess a secondary education $(65.1 \%)$, those with a basic or professional basic education were ranked second. Every tenth respondent declared having higher education (including those with Bachelor's degree) (see Table 6). Previously mentioned similarity of breakdowns of this variable in the sampling probe and in the 
population does not allow to formulate conclusions about the unequivocal primacy of the education's predication among subcultures' members due to the fact that the modal "secondary" may exclusively be a result of dominance of this category in the whole population of the young generation.

Table 6. Descriptive statistics - the breakdown regarding "education"

\begin{tabular}{|l|l|l|l|}
\hline Education & Pasic/basic professional & & 23.6 \\
\hline \multirow{4}{*}{ Important } & Secondary & & 65.1 \\
\cline { 2 - 4 } & Higher & 11.3 \\
\cline { 2 - 4 } & Total & 100.0 \\
\hline Lack of data & Systematic lack of data & & \\
\hline
\end{tabular}

Respondents, whose fathers have the basic or basic professional education constituted nearly half of the probed in the sampling $(40.8 \%)$. Approximately, the father of every third respondent has a higher education $(35.3 \%)$ and the remaining number of the probed are those respondents whose fathers have higher education (see Table 7). This breakdown in the context of "father's education" allows to conjecture about the evident negative covariance of subcultures' participation about fathers' education of subculture's members.

Table 7. Descriptive statistics - the breakdown regarding "your father's education"

\begin{tabular}{|l|l|l|l|}
\hline Your father's education & & Percentage \\
\hline \multirow{4}{*}{ Important } & Basic/basic professional & & 40.8 \\
\cline { 2 - 4 } & Secondary & 35.3 \\
\cline { 2 - 4 } & Higher & & 23.9 \\
\cline { 2 - 4 } & Total & 100.0 \\
\hline Lack of data & Systematic lack of data & & \\
\hline
\end{tabular}

The breakdown, which is described above, may lead to conceiving inconsiderate hypotheses about a strong prediction of subcultures' social status. However, a breakdown of the last variable about "financial situation" recommends caution and restraining from unequivocal assertions - the majority of respondents assessed their financial situation as good (very good $-10 \%$, rather good $-73.6 \%$ ) (see Table 8 ). The evaluation of the financial situation by respondents is certainly partial from their side and cannot prejudge a lack of deprivation among subcultures' members. Nonetheless, this deprivation seems to originate from another sphere of human existence.

Table 8. Descriptive statistics - the breakdown of the probed sampling regarding "financial situation"

\begin{tabular}{|l|l|l|l|}
\hline Financial situation & Percentage \\
\hline \multirow{4}{*}{ Important } & Very good & 10.0 \\
\cline { 2 - 4 } & Rather good & 73.6 \\
\cline { 2 - 4 } & Rather bad & 13.8 \\
\cline { 2 - 4 } & Very bad & 2.5 \\
\cline { 2 - 4 } & Total & 100.0 \\
\hline Lack of data & Systematic lack of data & \\
\hline
\end{tabular}


The undertaken sociological research is explorative for the majority of assertions and hypotheses made are intuitive rather than performed by induction. This approach allows formulating conclusions rather than it verifies (falsify) the existent knowledge. The verifications or comparisons were made where it was sociologically possible. In respect of large data obtained in the research, where there were many indicators for respondents' features, all these features were used in the analysis; or where preliminary analysis demonstrated a lack of significant differences between features, variables were synthesized into one variable and considered quantitatively. Each indicator is a variable corresponding to a specific feature, whose indirect observation is difficult. Indicators are features or phenomena. An indicator which is indicated is called indicatum. (Garlicki, 1991: 56-57)

All cited coefficients in the research describing relations between variables were oscillating from zero to $\mathrm{p}<0.05$. The research has not only confined itself to statistical recording existence of covariance but also provided a breakdown in crossing Tables between categories, all in conformity with the methodology of statistical analysis. (Gorniak - Machnicki, 2000; Nawojczyk, 2004) Apart from crossing Tables used for verification of conclusions, a method of linear regression analysis and a method of factor analysis (to obtain synthesized variables) were also used in the research. The authors are aware that not all obtained empirical data were analyzed and that many proposed interpretations are rather in the form of questions than answers. However, such an approach gives directions for further exploration and helps define characteristics which shape today's youth.

\section{Preferred moral values}

Moral values are essential in our exploration. They refer to concepts of human life and are most overriding and most important regulators of behavior in various spheres of life. They constitute a group of normative values which play a role of determinants of goals and aspirations as well as they are a point of departure in terms of evaluating judgments. A system of moral values of each person is being shaped in adolescence when an ability to issue judgments on moral issues, logical explanations, and linguistic expressions are formed.

Moral orientations are formed throughout adolescence as well. K. Kiciński enumerates four types of moral orientations:

The pro-societal orientation, where an individual does good for others and where precedence have actions for others than for oneself;

The dignified orientation, where an individual is an advocator of a particular ideal human, for example, lying and snitching on a person is considered by that individual as denigrating human values and dignity; The mutual orientation, based on a popular a bit divergent from a Catholic Golden Formula "Do unto others as you would have others do unto", where an individual behaves accordingly to how others approach that individual offering good actions and words for the same from others and offering bad actions and words for the same from others (Kiciński, 1983: 99);

The rigorous orientation (related to taboos) which draws on norms whose rationale do not need to be proven whether they are right or not, this orientation thus stands in opposition to those above where norms' rationale needs to be proven whether they are right or wrong, this orientation includes an element of fright.

There are three moral orientations among the surveyed population in the research: the mutual orientation ( $22 \%$ variances), the rigorous orientation ( $20 \%$ variances) and the pro-societal ( $20 \%$ variances). The results demonstrate that the young generation's development of moral orientation is not completed. Despite a component of "the pro-

XLinguae, Volume 12 Issue 2, April 2019, ISSN 1337-8384, eISSN 2453-711X 
societal orientation", co-existence of two orientations characterized by the lowest development of moral orientation occurs at comparable levels. These results exemplify the development of moral orientation which is typical for the whole population of young Poles and it does not only concern subcultures' members (see Table 9).

Table 9. The component analysis for the question "People are law-abiding because..."

\begin{tabular}{|l|l|l|l|}
\hline Component & \multicolumn{3}{|l|}{ Squares' sums of positions after rotation } \\
\hline & Total & \% variances & \% accumulated \\
\hline 1 & 1,540 & 22,006 & 22,006 \\
\hline 2 & 1,443 & 20,609 & 42,615 \\
\hline 3 & 1,409 & 20,134 & 62,750 \\
\hline
\end{tabular}

The method of distinguishing factors - Main Components

\begin{tabular}{|l|l|l|l|}
\hline Matrix of rotated components & \multicolumn{3}{l|}{ Squares' sums of positions after rotation } \\
\cline { 2 - 4 } & 1 & 2 & 3 \\
\hline $\begin{array}{l}\text { They gain other people's } \\
\text { respect }\end{array}$ &, 096 &,- 026 &, 837 \\
\hline They do more good to others &, 055 &, 203 &, 789 \\
\hline The can achieve more in life &, 762 &, 020 &, 142 \\
\hline They are prone to punishment &, 522 &, 482 &, 000 \\
\hline They have a clear conscience &, 321 &, 658 &, 254 \\
\hline Due to religious orders &,- 179 &, 857 &, 018 \\
\hline Easier to live on &, 735 &, 000 &, 034 \\
\hline
\end{tabular}

The method of distinguishing factors - Main components. The method of rotation Varimax with Kaiser's normalization.

The analysis of the correlation between a type of orientation and a type of subculture has not shown any significant correlation between variables; however, differences in hundreds' parts of each figure between categories are so considerable that we can indicate which moral orientations dominate among subcultures. The mutual orientation is relatively frequent among the following subcultures: the Punk, the HipHop, the Chav, the Metals, and is most seldom among the Skinheads. The rigorous orientation dominates among the Metals, less frequent among the Hip-Hops, the Chavs, and the Skinheads. The last distinguished component - the pro-societal orientation - dominate among the Skinheads, then the Hip-Hops, the Chavs, and is most seldom among the Punks and the Metals (see Table 10, 11, 12). Summing up, the Skinheads are most mature morally, and the Metals and the Punks are least mature morally. 
Table 10. The crossing Table of variable: "What is the name of subculture you belong to?" and of the component "mutual orientation"

\begin{tabular}{|c|c|c|c|c|c|c|}
\hline \multirow[t]{2}{*}{ Mutual } & & \multicolumn{4}{|c|}{ Subculture } & \multirow[t]{2}{*}{ Total } \\
\hline & & Punk & Metal & Skinhead & $\begin{array}{l}\text { Hip- } \\
\text { hop/chav }\end{array}$ & \\
\hline \multirow{2}{*}{$\begin{array}{l}\text { No } \\
\text { answer }\end{array}$} & & & & & & \\
\hline & $\begin{array}{l}\% \\
\text { subculture }\end{array}$ & $15.2 \%$ & $27.8 \%$ & $31,6 \%$ & $24,3 \%$ & $24,0 \%$ \\
\hline \multicolumn{7}{|l|}{ Yes } \\
\hline & $\begin{array}{l}\% \\
\text { subculture }\end{array}$ & $84,8 \%$ & $72,2 \%$ & $68,4 \%$ & $75,7 \%$ & $76,0 \%$ \\
\hline \multicolumn{7}{|l|}{ Total } \\
\hline & $\begin{array}{l}\% \\
\text { subculture }\end{array}$ & $100,0 \%$ & $100,0 \%$ & $100,0 \%$ & $100,0 \%$ & $100 \%$ \\
\hline
\end{tabular}

Person's Chi square $=4,597 ; \mathrm{df}=3$; asymptotic materiality (reciprocal) $=, 204$

Table 11. The crossing Table of variable: "What is the name of subculture you belong to?" and of the component "rigorous orientation"

\begin{tabular}{|c|c|c|c|c|c|c|}
\hline \multirow[t]{2}{*}{ Rigorous } & & \multicolumn{4}{|c|}{ Subculture } & \multirow[t]{2}{*}{ Total } \\
\hline & & Punk & Metal & Skinhead & $\begin{array}{l}\text { Hip- } \\
\text { hop/chav }\end{array}$ & \\
\hline \multirow{2}{*}{$\begin{array}{l}\text { No } \\
\text { answer }\end{array}$} & & & & & & \\
\hline & $\begin{array}{l}\% \\
\text { subculture }\end{array}$ & $25.0 \%$ & $17.6 \%$ & $35,0 \%$ & $26,5 \%$ & $25,0 \%$ \\
\hline \multicolumn{7}{|l|}{ Yes } \\
\hline & $\begin{array}{l}\% \\
\text { subculture }\end{array}$ & $75,0 \%$ & $82,4 \%$ & $65,0 \%$ & $73,5 \%$ & $75,0 \%$ \\
\hline \multicolumn{7}{|l|}{ Total } \\
\hline & $\begin{array}{l}\% \\
\text { subculture }\end{array}$ & $100,0 \%$ & $100,0 \%$ & $100,0 \%$ & $100,0 \%$ & $100 \%$ \\
\hline
\end{tabular}


Table 12. The crossing Table of variable: "What is the name of subcultures you belong to?" and of the component "pro-societal orientation"

\begin{tabular}{|c|c|c|c|c|c|c|}
\hline \multirow[t]{2}{*}{ Mutual } & & \multicolumn{4}{|c|}{ Subculture } & \multirow[t]{2}{*}{ Total } \\
\hline & & Punk & Metal & Skinhead & $\begin{array}{l}\text { Hip- } \\
\text { hop/chav }\end{array}$ & \\
\hline \multirow{2}{*}{$\begin{array}{l}\text { No } \\
\text { answer }\end{array}$} & & & & & & \\
\hline & $\begin{array}{l}\% \\
\text { subculture }\end{array}$ & $52.9 \%$ & $48.6 \%$ & $36,8 \%$ & $43,2 \%$ & $46,4 \%$ \\
\hline \multicolumn{7}{|l|}{ Yes } \\
\hline & $\begin{array}{l}\% \\
\text { subculture }\end{array}$ & $47,1 \%$ & $51,4 \%$ & $63,2 \%$ & $56,8 \%$ & $53,6 \%$ \\
\hline \multicolumn{7}{|l|}{ Total } \\
\hline & $\begin{array}{l}\% \\
\text { subculture }\end{array}$ & $100,0 \%$ & $100,0 \%$ & $100,0 \%$ & $100,0 \%$ & $100 \%$ \\
\hline
\end{tabular}

Person's chi square $=2,995 ; \mathrm{df}=3$; asymptotic materiality (reciprocal) $=, 392$

The described observations indicate a general breakdown of moral orientations among subcultures' members. An association with absolutely universal moral norms is limited and depends on particular situations. The above empirical research shows prevalence (without a defined range) of moral immaturity and moral permissiveness. The results are analogical with the research undertaken for the whole population of Poles: "the faltering of general moral norms and a lack of their abiding strength, which translates into a weakening of criteria for individual and collective choices, can be read as a symptom of distinctive moral crisis. Many young Poles question basic notions of moral good and bad. [...] More permissive attitudes of young people can be transitional and linked with their current life situation. As they grow older, their opinions will undergo further evolution, not necessarily consistent with their present direction. Independently of differences between generations, we can talk about a tendency to a "permissive society"'. (Marianski, 2001: 187; for an analysis of this crisis from a Christian theology's perspective, see: Bahovec, 2015)

Summing up, a notion of values throughout life of those that belong to youth subcultures changes rapidly. Present theories concerning the genesis and activities of subcultures do not entirely explain why current subcultures have come to existence. Here comes to mind an example of the theory on cultural transmission. This theory, propagated by Clifford Shaw, H. MacKay, Frederic Thrasher, Walter B. Miller (Rowinski, 2004: 16), provide mechanisms describing the formation of autonomic circles of youth which are an alternative environment making up for deficiencies at home, becoming a center of expressing oneself and centers of entertainment. Nonetheless, the theory does not offer explanations about formations of present subcultures where not all its members adopt behaviors of lower layers. Other theories, such as R.K. Merton's theory of anomy showing a resonance between norms, cultural goals social possibilities of their realisation (Merton, 2005: 583-585), or theories of cultural conflict (William I. Thomas, Florian Znaniecki, T. Sellin) (Siemaszko, 1993: 163) postulating that subcultures, are the product of a conflict of cultures stemming from social chaos and intergenerational conflicts. According to the latter, intergenerational conflicts lead to a weakening of relations between a parent and a child, weakening of family links, isolation of the child's world from that of the parents, and all these ultimately lead to seeking emotional links outside the family. The young seek for themselves other solutions without taking into account a relation 
with the currently abiding cultural norms (Muller, 1987: 30-33). The theory postulates that the isolation of older people's environment from the younger people's environment; the older people's attachment to traditional values and norms; their common reluctance to novelties are the causes of the conflict. That said, it is difficult to agree with this theory definitively. One should rather say that this theory is only valid for a group of young people amid subcultures. Judging from the present research, the contemporary formation of subcultures has its specifics.

A willingness to stress one's individuality; a need to find one's place in the world; his or her aspiration for stabilization; and search for one's identity are considered significant and influence how subcultures are formed. In adolescence, changes that occur in terms of his or her physics go in parallel with changes in the psychological sphere. During that time, abstract and deductive thinking appears together with reflexive and critical attitudes towards reality. It often occurs that a young person challenges prevailing socio-cultural norms which social institutions such as family and school pass on the person. The person then reaches out to those that have similar views and perceive reality likewise. Through that process of reaching out, subcultures are formed, or some individuals join already existing subcultures. It seems that defiance, which is typical for adolescence; a need to distinguish oneself from others; a need to search its path to follow and to present herself or himself as a "hero" who dares to gainsay and not to give up, bring about that a person joins a subculture. The fact of joining the subculture does not mean that the person associates himself or herself straight away with the subculture, but could do it to show off or become popular in a group of people. It must be remembered that the time of adolescence is the time of shaping one's imagination and being absorbed by his or her personality and physics. It is connected with ideas concerning his or her style of living, dressing, behaving and listening to a particular type of music. Such ideas can be a manner of escape from difficult situations and failures occurred in life. Moreover, young people generally underestimate the potential of being open to transcendence (Bravena, 2016: 156). Most of such young people do not concentrate on hedonistic goals but focus instead on affirming their values in acts of defiance, in extreme actions, etc., i.e., in negative self-transcendence, which affects the destruction of the personality ("homo transcendence and the negative overlap") (Bravena, 2016: 74-75). Subculture can be formed in the background described above.

A problem of disillusionment by the world of adults, to which he or she is acceding and for which he or she is ill-prepared socially, is another important issue in this context. Some persons find their place easily in the world of adults and their axiology while others experience difficulties. M. Filipiak refers to an attitude of conflict and explains subcultures connecting them with the intergenerational conflict. (Filipiak, 1999: 10) In that context, the attention needs to be drawn to a role and functions of the family, as the body which socializes the young person, educate him or her, transmits certain values and prepares him or her for life. It often occurs that the axio-normative system of the adults will not be favored by the young. Besides, there are, at times, schemes of behavior which adults do not use, or use selectively, in their adult age this evokes disillusionment because those who teach, do not abide themselves by moral norms. Then, the young realize that they may disregard norms and rules. Such a loss of a point of reference for values and norms can lead to a weakening of family links and searching alternative groups which the young person considered as potentially fulfilling his axio-normative world. Subcultures often fill the gap by gathering persons who share similar views and values.

\section{Socialization of subcultures}

A process of socialization of the contemporary youth participating in various subcultures is an important issue. It is common knowledge that socialization is the

XLinguae, Volume 12 Issue 2, April 2019, ISSN 1337-8384, eISSN 2453-711X 
process of adaptation of an individual to live in a society, a process of acquiring indispensable capacities, adaptive abilities to function by social norms and co-exist in the society including through playing its own social roles.

There are several definitions of socialization. Z. Tyszka postulates that it is "a process of accruing to the culture which prepares for the execution of tasks stemming from defined social roles." (Tyszka, 1979: 43) F. Elkin and G. Handel offer another definition - "a process, in which a person absorbs mandatory norms of the society or the social group, and through that he or she may function in that society or the group." (Blejwas, 1997: 67) Instead, M. Przetacznik claims that socialization constitutes a process of "going through from individual activities to collective activities which are conducted in cooperation by a group of individuals." (Przetacznik-Gierowska Wlodarski, 1994: 90) Other researchers dealing with the societal life postulate that socialization is "a formation of preferred personality traits and pro-societal attitudes" (Reykowski - Kochanska, 1980: 36) as well as "an ability to take up and perform collective activities" (Strelau, 2000: 94).

Subsequently, the socialization of an individual constitutes a process of preparing him or her for life in the context of a wide range of complex social relations. Taking into account an aspect of education, it has to be acknowledged that the socialization cannot continue without social circumstances which a young individual is confronted within his or her future. The education should be an introduction of the young individual into the whole spectrum of collective life offering him or her the understanding of its rules and regulations, transmitting him or her abilities to actively participate in the social life which would then contribute to developing in him or her a sense of care for the common good. It must be stressed that the socialization and the attainment of a societal maturity is a result of the social development of the young individual. The latter includes abilities to co-exist in the society, relations with others, social needs which occur in various periods of life and socially various environmental circumstances. The societal maturity of the individual or its differing levels stem from family- related complex educative influences and the closest social environment surrounding the individual. The socialization is a long-term process and depends upon many factors with which the individual is confronted throughout his or her life and in contacts with social groups. Subsequently, the process of socialization produces changes in an individual's attitudes which ensue from influences of a particular group, or a subculture group. The changes aforementioned are those related to the personality traits of a young individual. This individual adapts himself or herself to the collective life, and the more popular the group is, to which he or she belongs or sympathizes with, the more socialized he or she becomes in the course of the social development. A positive result of the socialization embraces an ability of comprehension of others, intelligent actions in the framework of collectiveness as well as generates attitudes which allow the individual to achieve his or her life goals. Thus, it can be said that the socialization is a product of the adequate social development of the individual and the aggregate of social behaviors of the young individual mirrors his or her level of the societal maturity. Therefore, the latter aspect is taken into account in many societal types of research.

M. Ossowska considers the socialization as one of the most important dispositions of the personality pattern. (Ossowska, 1992:84) The socialization entails a collection of directives favoring the organization of the collective life such as responsibility and tolerance. These attributes pertain to wider social circles, social subjects and social institutions. Individuals of the pro-social attitude are oriented towards an institutionwise and a group-wise frame of reference or towards the good of other individuals in opposition to those individuals which overall seek their profit and are entirely focused on themselves. (Marianski, 1990:156-157) It is acknowledged that the manifestation of such an attitude is the indicator of harmonious moral development of the individual. 
That said, the issues of responsibility and tolerance deserve the highest attention as far as surveyed subcultures' groups are concerned.

The issue of responsibility is a basic concept in terms of humanistic considerations accentuating human dignity, freedom, subjectivism, abilities to act consciously and purposefully which ensue from acknowledged values. (Ambrózy, 2017) This concept pertains to morality and ethics - criteria of guilt and merits, conditions and types of responsibility for a particular behaviour. It is closely linked with practical activities of people, collectively and individually, regulated by accepted norms and judged morally." The dictionary of the societal catholic science" describes responsibility as "a relation of an object towards his or her own, free and conscious actions, which leads to a situation where the object bears consequences of his or her actions. According to R. Ingarden, responsibility is connected with the four following types of experience: 1) someone bears responsibility for something; 2) someone takes responsibility for something; 3) someone is made accountable for something; 4) someone acts responsibly (...). Responsibility draws on experiences of justice and love. In the name of justice, an object is responsible for his or her own, free and conscious actions, whereas, in the name of love, responsibility includes what is considered as "own" as well as negative consequences of other peoples' actions." (Podrez, 1993: 117) Responsibility is a positive duty of love towards a collectiveness which orders to act in a manner to behold and enrich this collectiveness. In ordinary situations, this duty translates into a proper performance of his or her human-wise, family-wise and profession-related tasks. Instead, in extraordinary situations where the collectiveness is threatened by a political, cultural, economic dangers, the performance of the duty requires actions of a great commitment, including a sacrifice of life. (Piwowarczyk, 1957: 282)

In this analysis, personal experience of individual and collective responsibilities for the fate of the collectiveness, its present and future, is the most important aspect of axiological order's resultant in "mezzo" and "macro" dimensions. This type of responsibility is an instrumental value underlying human actions. At the same time, it is an autotelic value for its realization does not bring and profits to the one that is bearing that responsibility. (Koreach, 1985) Thus, the one that is responsible is the person who reaches out beyond personal values. In the normative sense, for example, a teacher is responsible who manifests a sense of responsibility. "A sense of responsibility is knowledge about himself or herself, other people, a surrounding environment as well knowledge about his, her duties towards the surrounding environment." (Ostrowska, 1995: 31) This sense of responsibility incites individuals to particular actions, to cease or interrupt them and constitutes an ethical base for actions. (Homplewicz, 1996: 157) The essence of a truly mature responsibility for someone perceives his or her needs and interests. An ethically mature man or woman is he or she who deeply feels responsible for someone or something. (Olearczyk, 1990: 26) Thus, a question is born: "Why some individuals want or are responsible?" and "Why do they feel responsible for the fate of their collectiveness?" Z. Kwieciński enumerated the three following groups of conditions:

- "Firstly - due to the possessed value to a consequent use of earlier internalized moral rules, i.e., the acquisition of moral behavior's imperatives and abilities to solve moral conflicts following ethical rules by an individual;

- Secondly - a basic and universal component of competence for responsibility is kindness towards other people in need of care, support, help, direction;

- Thirdly - a motive towards responsible actions for other people and for undertaken duties may be a desire to achieve a professional, prestigious and financial success. (Kwiecinski, 1998: 31) 
To this catalog, due to the nature of our research, interesting conditions enumerated by D. Birnbacher should be mentioned and added:

1. A hypothetical possibility of influences: the more irreversible is a catastrophe, the smaller is the readiness for an active intervention" (Birnbacher, 1999: 175);

2. A hypothetical likelihood of the interested: "He who sees himself in accordance with his image as a socialist, he sees a socialist from a remote culturally nation as more similar to him than whoever else; he, who defines himself through his affiliation to a given cultural circle" (Birnbacher, 1999: 175);

3. A temporal closeness: "If it was certain that people who are decisively similar to us would live in ten generations after us (...) our readiness to show a regard for them will be far smaller" (Birnbacher, 1999: 175176).

According to D. Birnbacher, the latter distinctions concern a sense of responsibility for the future of social groups. In our research, instead, we will concentrate on a sense of responsibility of groups at present times, "here and now". However, we will try to determine whether the hypothetical possibility of influences and the hypothetical likelihood of the interested will have a predicament strength in the case of the surveyed groups.

\section{Responsibility of subcultures' members}

The surveyed youth of all subcultures is characterized by the greatest sense of responsibility for their natural peer groups such as groups of friends, school groups, and social youth groups. Ranked second is the sense of responsibility for direct natural groups such as family, local community, religious group and the Church. The weakest sense of responsibility is felt for the nation and the state.

Nevertheless, as expected, there are significant differences between the declarations made by particular subcultures' groups. The punk shows the greatest responsibility for friends, family and their youth group (50\% of the surveyed) and the weakest responsibility for religious groups and the Church. It demonstrates an anti-religious character of the Punk ideology as well as their cultural contestation of certain values.

Table 13. Descriptive statistics - the arithmetical average of the standard deflection for the question: Below are listed some communities and social groups. For which do you feel responsible? The Punk group

\begin{tabular}{|l|l|l|l|}
\hline Punk & N & Average & Standard deflection \\
\hline Group of friends & 88 & 1,0000 &, 00000 \\
\hline Family & 88 &, 9091 &, 28913 \\
\hline Youth group & 72 &, 7778 &, 41866 \\
\hline Nation & 74 &, 4865 &, 50323 \\
\hline School group & 78 &, 4615 &, 50175 \\
\hline Local community & 76 &, 3684 &, 48558 \\
\hline State & 82 &, 2439 &, 43208 \\
\hline Church & 86 &, 2093 &, 40920 \\
\hline Religious group & 78 &, 1026 &, 30535 \\
\hline
\end{tabular}

While analyzing the Punk subculture in Poland, it has to be said that this subculture is a very diversified group as far as its views are concerned. Some Punks represent anarchistic, communist and even nationalistic views. There are also apolitical Punks. By the same token, the subculture does not have any unified and common ideology except "for freedom" attitude. One of the representatives of this subculture said: "the Punk is overall freedom, it is a rebellion against limitations created by the state, 
politics, the society which does not accept us" (Interview with the subculture's representative, Agnieszka, 22 years old). Instead, while comparing the Punk group to other subcultures, there are significant discrepancies in their views. Hence, independently of their internal ideological divisions, all Punks declare the sense of responsibility for friends of peer groups to which they belong.

Table 14. Descriptive statistics - the arithmetical average, the standard deflection for the question: Below are listed some communities and social groups. For which do you feel responsible? The Metal group.

\begin{tabular}{|l|l|l|l|}
\hline Metal & $\mathrm{N}$ & Average & Standard deflection \\
\hline Group of friends & 90 & 1,0000 &, 00000 \\
\hline Family & 90 &, 9556 &, 20723 \\
\hline Nation & 78 &, 6667 &, 47446 \\
\hline Youth group & 76 &, 6053 &, 49204 \\
\hline State & 76 &, 4474 &, 50053 \\
\hline School group & 84 &, 3810 &, 48854 \\
\hline Local community & 84 &, 3571 &, 48204 \\
\hline Religious group & 76 &, 2105 &, 41039 \\
\hline Church & 80 &, 2000 &, 40252 \\
\hline
\end{tabular}

The breakdown of answers by the Metal group and the Hippie group is similar to answers provided by the Punk group. However, the group, most often, indicated the sense of responsibility for friends, family, their youth group, and most seldom pointed at the sense of responsibility for religious groups and the Church. However, the sense of responsibility shown by the Metal group for the nation is far bigger than among the Punk group (50\% of the surveyed).

The surveyed subculture youth is characterized by the biggest sense of responsibility for natural peer groups such as groups of friends, school groups, their youth groups, and family. The smallest sense of responsibility was shown for religious groups, the Church, the nation, the State and the local community (See Table 15).

Table 15. Descriptive statistics - the arithmetical average, the standard deflection for the question: Below are listed some communities and social groups. For which do you feel responsible? The Hippie group.

\begin{tabular}{|l|l|l|l|}
\hline Hippie & $\mathrm{N}$ & Average & Standard deflection \\
\hline Group of friends & 32 & 1,0000 &, 00000 \\
\hline Family & 30 &, 8667 &, 34575 \\
\hline Youth group & 32 &, 7500 &, 43994 \\
\hline Nation & 26 &, 5385 &, 50839 \\
\hline School group & 30 &, 5333 &, 50742 \\
\hline Local community & 26 &, 2308 &, 42967 \\
\hline State & 28 &, 2143 &, 41786 \\
\hline Religious group & 30 &, 2000 &, 40684 \\
\hline Church & 28 &, 1429 &, 35635 \\
\hline
\end{tabular}


Table 16. Descriptive statistics - the arithmetical average, the standard deflection for the question: Below are listed some communities and social groups. For which do you feel responsible? The Skinhead group.

\begin{tabular}{|l|l|l|l|}
\hline Skinhead & $\mathrm{N}$ & Average & Standard deflection \\
\hline Group of friends & 54 & 1,0000 &, 00000 \\
\hline Family & 52 &, 8846 &, 32260 \\
\hline Nation & 56 &, 8571 &, 35309 \\
\hline Youth group & 44 &, 8182 &, 39015 \\
\hline Local community & 42 &, 7619 &, 43108 \\
\hline State & 46 &, 6957 &, 46522 \\
\hline Religious group & 52 &, 3462 &, 48038 \\
\hline School group & 48 &, 2500 &, 43759 \\
\hline Church & 52 &, 2308 &, 42544 \\
\hline
\end{tabular}

The Skinhead group constitutes the biggest "social world" in our analysis with the biggest declared social responsibility. More than half of the surveyed showed the sense of responsibility in the following order: friends, family, the nation, their youth group, their local community and the state. The Skinhead group differs, in terms of quantity and quality, from other subcultures. By their ideology, they acclaim their affiliation with and the sense of responsibility for the State. However, as far as the sense of responsibility for religious groups and the Church is concerned, they do not differ from other surveyed groups, only every third respondent declared responsibility for religious groups and every fifth for the Church (see Table 16).

The Hip-hop/chav subcultures were analyzed subsequently. These subcultures, next to the Punk group, have the weakest indicator of the sense of responsibility (shown by over $50 \%$ for three social groups). However, in terms of the sense of responsibility, they showed the biggest proportion of positive declarations concerning family, then subsequently for groups of friends and their youth group. This observed familiarisation is very specific for the whole population of Poles - where, most habitually, the Polish sense of affinities with family correlates with the Polish sense of affinities with the Church and religious groups. In this case, we have an opposite situation where the indicator of the sense of responsibility for religious groups and the Church for the Hip-hop/Chav groups is the lowest (See Table 17).

Table 17. Descriptive statistics - the arithmetical average, the standard deflection for the question: Below are listed some communities and social groups. For which do you feel responsible? The Hip-hop/Chav groups.

\begin{tabular}{|l|l|l|l|}
\hline $\begin{array}{l}\text { Hip-hop/Chav } \\
\text { groups }\end{array}$ & $\mathrm{N}$ & Average & Standard deflection \\
\hline Family & 100 &, 9800 &, 14071 \\
\hline Group of friends & 100 &, 9000 &, 30151 \\
\hline Youth group & 92 &, 7609 &, 42889 \\
\hline Local community & 102 &, 4902 &, 50237 \\
\hline Nation & 92 &, 4565 &, 50084 \\
\hline School group & 92 &, 4130 &, 49508 \\
\hline State & 84 &, 3571 &, 48204 \\
\hline Religious groups & 88 &, 2955 &, 45886 \\
\hline Church & 84 &, 2381 &, 42848 \\
\hline
\end{tabular}

Summing up, the issue of responsibility is not a very important factor for the surveyed. However, it cannot be said that it is perceived as entirely not important. Unquestionably, the closest social environment, i.e., family and friends constitute the proportionally strongest areas of the analyzed senses of responsibility. Luckily, these 
are not in competition with civic society. The analysis of correlations demonstrates that the sense of responsibility for family or friends is not detrimental to the State, the local community or other social groups. The below component analysis presents declarations of strong affinities between the family community and the local community - it may be concluded that the family community, the local community and the congregation form one common area of the social identity (see Table 18).

Table 18. The component analysis for the question: Below are listed some communities and social groups. For which do you feel responsible?

\begin{tabular}{|l|l|l|l|}
\hline Component & \multicolumn{3}{|l|}{ Squares' sums of positions after rotation } \\
\hline & Total & $\%$ variances & $\%$ accumulated \\
\hline 1 & 1,914 & 21,262 & 21,262 \\
\hline 2 & 1,579 & 17,541 & 38,803 \\
\hline 3 & 1,436 & 15,958 & 54,760 \\
\hline
\end{tabular}

The method of distinguishing factors - Main Components

\begin{tabular}{|l|l|l|l|}
\hline \multirow{2}{*}{$\begin{array}{l}\text { Matrix of rotated } \\
\text { components }\end{array}$} & \multicolumn{3}{|l|}{ Squares' sums of positions after rotation } \\
\cline { 2 - 4 } & 1 & 2 & 3 \\
\hline Family &, 434 &, 149 &,- 134 \\
\hline Local community &, 401 &, 182 &, 348 \\
\hline Nation &, 133 &, 869 &, 046 \\
\hline Religious groups &, 836 &, 146 &, 087 \\
\hline School group & & &, 490 \\
\hline Church &, 148 &, 189 &, 071 \\
\hline State &, 862 &, 044 &, 093 \\
\hline Group of friends &, 200 &, 833 &, 685 \\
\hline Youth group &,- 198 &, 053 &, 752 \\
\hline
\end{tabular}

The method of distinguishing factors - Main components. The method of rotation Varimax with Kaiser's normalization.

In this case, it must be stressed that the above Table shows a contrast. The more sense of responsibility for family and friends grows, the more the sense of responsibility grows for the state and the local community. The lack of the sense of responsibility in the case of the two latter is not a consequence of the diagnosed familiarisation, which in any event may lead to the creation of a hermetic community, but a consequence of the lack of the sense of responsibility which subsequently indicates a deficiency of a moral maturity of the surveyed.

A moral maturity, defined as readiness for concluding agreements with other people as well as an orientation towards fixed rules and conscience is the highest phase of the moral development of an individual. It is not the knowledge about what is moral or not, but the knowledge about what should be considered moral and which rules should guide our lives and which goals should be achieved. Thus, it can be stated that, in the light of the conducted sociological research, the value of responsibility is not fully the internalized value for the surveyed, i.e., the value which guides and regulates the human behavior. Since the results of the research are not optimistic, and the issue of

XLinguae, Volume 12 Issue 2, April 2019, ISSN 1337-8384, eISSN 2453-711X 
responsibility is essential for proper social development of the society as a whole, this topic a fortiori reveals an unquestionable need to be further conscientiously and meticulously examined by sociological researchers.

\section{Conclusion}

The conducted research confirms the link between the quality of the youth's socialization and socializing communities such as family, school, peer groups and the media. The quality of responsibility attitudes of subcultures' members depends on the quality of the socializing impact of the aforementioned socializing communities. It is apparent that the responsibility attitude is not the fully internalized value among the subcultures' members, i.e., the value which guides and regulates human behavior. In the context of the latter, it has to be mentioned that the surveyed subcultures' youth declared, in a decisive manner, their sense of responsibility for their own family. Hence, it can be judged that this socializing body leaves its indelible mark. Moreover, the following postulates have been made in the course of the research:

1. The socialization by media provokes a spread and provision of information about the world and the society of the young.

2. Easy access to information, ideals, values linked with phenomena of subcultures contributes to the decision making by the young to join a subculture group.

The mass media become the principal source of knowledge about subcultures. (Pal'a, 2015) They facilitate the rapid acquisition of information about each particular subculture group. Once, in order to gain knowledge about a subculture, one had to speak to a subcultures' representative. Undoubtedly, today there are more simple manners to find out about the features of each group. A young person may draw on information about subcultures from multiple sources of publications, including academic ones, magazines and internet pages. (Centa, 2012) The knowledge about youth subcultures, so easily accessible, provokes a growth of interest among the young, which in turn causes a formation of subcultures in new places.

Hence, in the context of security, it is important to concentrate on prevention and counteraction stemming from dangers of anti-social functions of some subcultures. They can cause considerable interruptions in societal relations, even breach the law. Therefore, some subcultures are considered as menaces to the public and social orders by internal security agencies.

In order to accurately evaluate a subculture group (its ideology, forms of behavior of its members, as well as causes of its creation in a particular place), empirical research has to be constantly conducted to diagnose existent subcultures' phenomena among the young. Only a meticulous sociological diagnosis can help suitable agencies and bodies apply specific prophylactic and preventive measures to assure the physical and personal security of citizens of the state. These preventive measures will necessarily include intentional cultivation of human character in the context of both, institutionalized education and informal activities aimed at character development and value formation in the environment of free, non-governmental agencies and associations. This process must be personal (and person-oriented) (Dancak, 2014) and existential (Pavlikova, 2017; Petkovsek, 2016), while treating all humans as persons with their inalienable dignity which must never be "reduced to utilitarian concepts." (Malovic, 2007: 56)

\section{Acknowledgments}

1. The work is performed according to the Russian Government Program of Competitive Growth of Kazan Federal University.

2. The publication has been prepared with the support of the "RUDN University Program 5-100". 


\section{Bibliographic References}

BAHOVEC, I. 2015. Christianity in confrontation with individualism and crisis of western culture: person, community, dialog, reflexivity, and relationship ethics. In: Bogoslovni Vestnik, vol. 75, issue 2, pp. 335-346.

BATURA, W. 2008. Katastrofy i zagrożenia we współczesnym świecie. Warszawa: Wydawnictwo Naukowe PWN.

BAUMAN, Z. 1992. Nowoczesność i zagłada. Warszawa.

BĄK, T. 2008a. Subkultura psychobilly. In: Zeszyty Naukowe Instytutu Socjologii PWSZ w Tarnobrzegu. Tarnobrzeg, 2008, pp. 9-33.

BĄK, T. 2008b. Typologia współczesnych subkultur młodzieżowych. In: Społeczeństwo polskie w procesie zmian. Warszawa, UKSW, pp. 108-119.

BĄK, T. 2008c. Współczesne uwarunkowania kreacji subkultur młodzieżowych. Warszawa: Wydawnictwo UKSW.

BĄK, T. 2009. Młodzież a subkultury w realiach polskiego społeczeństwa. In: Bąk, T. - Majkowski, W. (eds.): Kultura polska. Kierunki i dynamika zmian. Warszawa, pp. 71-85.

BAUMAN, Z. 1992. Nowoczesność i zagłada. Transl. by Jaszuński F., Warszawa: Fundacja kulturalna.

BIRNBACHER, D. 1999. Odpowiedzialność za przyszłe pokolenia. Warszawa: Oficyna Naukowa.

CENTA, M. 2012. Negative influence of the media and social environment on the values and self-image of adolescent girls. In: Bogoslovni Vestnik, vol. 72, issue 3, pp. DANCAK, P. 2014. The personalist view of the education in the philosophy of $\mathbf{J}$. Maritain. In: Studia Theologica Babes Bolyai Studia Catholica, vol. 59, issue 1-2, pp. 133-142.

EARL, B. 2004. Badania społeczne w praktyce. Warszawa: PWN.

FILIPIAK, M. 1999. Od subkultury do subkultury alternatywnej. Lublin: Wydawnictwo UMCS.

GARLICKI, J. 1991. Kultura polityczna młodzieży studenckiej. Warszawa: PWN.

GORNIAK, J. - MACHNICKI, J. 2000. Pierwsze kroki w analizie danych - SPSS for Windows. Kraków: SPSS Polska.

HOMPLEWICZ, J. 1996. Charakterystyka i uzasadnienie etyki pedagogicznej. In: Sareło Z. (ed.): Moralność i etyka w ponowoczesności. Warszawa.

KICINSKI, K. 1983. Społeczne determinanty orientacji moralnych. In: Etyka vol. 20, pp. 90-103.

KOREACH, M. 1985. Value survey. In: Halgren tests. Sunnyvale CA.

KWIECINSKI, Z. 1998. Struktura i treść odpowiedzialności nauczycielskie i pedagogicznej. Zarys problematyki. In: Tchórzewski, A. M. (ed.): Odpowiedzialność jako wartość i problem edukacyjny. Bydgoszcz: Wydawnictwo WERS, p. 31.

MALOVIC, N. 2007. Ljudsko Dostojanstvo Izmedu Znanosti I Svjetonazora. In: Bogoslovska Smotra, vol. 77, issue 1, pp. 43-57.

MARIANSKI, J. 1990. Moralność w procesie przemian. Warszawa: PAX, pp. 156157.

MARIANSKI, J. 2001. Kryzys moralny czy transformacja wartości studium socjologiczne. Lublin: TN KUL, 187 p.

MERTON, R. T. 2005. Struktura społeczna i anomia. In: Sztompka, P. - Kucia, M. (eds.): Socjologia. Lektury. Kraków: Wydawnictwo Znak, pp. 583-585.

MLYNARSKI, S. 2000. Praktyczne metody analizy danych rynkowych i marketingowych. Zakamycze.

MULLER, T. 1987. Młodzieżowe podkultury. Warszawa: Wiedza Powszechna.

NAWOJCZYK, J.M. 2004. Przewodnik po statystyce dla socjologów. Kraków: SPSS Polska.

XLinguae, Volume 12 Issue 2, April 2019, ISSN 1337-8384, eISSN 2453-711X 
OLEARCZYK, T. 1990. Sprawa odpowiedzialności w wychowaniu. In: Nowa szkoła. I., 1990, p. 26.

OSSOWSKA, M. 1992. Wzór demokraty. Lublin: Daimonion.

OSTROWSKA, K. 1995. Poczucie odpowiedzialności jako element dojrzałej osobowości. In: Olbrycht, K. (ed.): Edukacja aksjologiczna. Odpowiedzialność pedagoga, Vol. 2. Katowice: Wydawnictwo Uniwersytetu Slanskiego.

PALA, G. 2015. The Family in Media Ciphers. In: European Journal of Science and Theology, vol. 11, issue 6, p. 45-56. ISSN 1841-0464.

PAVLIKOVA, M. 2017. Reading Auden as a Resource for Existential Reflection in a Society with Technocratic and Hedonistic Tendencies. In: Communications Scientific Letters of the University of Zilina, vol. 19, n. 1, pp. 39-43. ISSN 1335-4205. PETKOVSEK, R. 2016. Spomin kot obljuba: pogled z vidika mimetične teorije in hermenevtike eksistence. In: Bogoslovni Vestnik, vol. 76, issue 3/4, pp. 495-508.

PIWOWARCZYK, J. 1957. Katolicka nauka społeczna. Vol. 1., Londyn.

PODREZ, E. 1993. Odpowiedzialność. In: Piwowarski W. (ed.): Słownik katolickiej nauki społecznej. Warszawa: PAX.

PRZETACZNIK-GIEROWSKA, M. - WŁODARSKI, Z. 1994. Psychologia wychowawcza. Warszawa: WN PWN.

REYKOWSKI, J. - KOCHAŃSKA, G. 1980. Szkice z teorii osobowości. Warszawa: Wiedza Powszechna.

ROWIŃSKI, G. 2004. Socjologiczno-psychologiczna analiza grup wyznaniowych w Polsce. In: Podkultury i nowe ruchy religijne w Polsce. Warszawa: Scholar.

SIEMASZKO, A. 1993. Granice tolerancji. O teoriach zachowań dewiacyjnych. Warszawa: PWN.

SIMMEL, G. 1975. Socjologia. Transl. by Łukaszewicz M., Warszawa.

SLIVKA, D. - MIERZWA, J. 2017. Intentional Abuse of Social Networks with the Goal of Promoting Ideas of Anti-Semitism, Xenophobia, and Racism. In: Komunikacie, vol. 19, issue 1, p. 54-58. ISSN 1335-4205.

STRELAU, J. 2000. Psychologia. Podręcznik akademicki tom II. Gdańsk: GdańskieWydawnictwo Psychologiczne.

SZTABIŃSKI, F. 2000. Narzędzie badawcze i jego elementy. In: Sawiński, P.B. Sztabiński, F. (eds.): Podręcznik ankietera. Warszawa: IfiS PAN, 2000, pp. 50-54.

SWIDA, H. 1999. Wartości egzystencjalne młodzieży lat dziewięćdziesiątych. Warszawa: Uniwersytet Warszawski.

TYSZKA, Z. 1979. Socjologia rodziny. Warszawa: PWN.

Words: 10198

Characters: 67470 (37,5 standard pages)

Prof. nadzw. Dr hab. Tadeusz Bąk, PhD.

Institute of Economy and Management

The Bronisław Markiewicz State Higher School of Technology and Economics in Jarosław (PWSTE in Jarosław)

ul. Czarnieckiego 16,

37-500 Jarosław

Poland

tedbak@wp.pl

doc. ThDr. Mária Kardis, PhD.

Department of Historical Sciences

Greek Catholic Theological Faculty

The University of Presov in Presov

Ul. Biskupa Gojdica 2

08001 Presov 
Slovak Republic

maria.kardis@unipo.sk

Prof. PhDr. Michal Valco, PhD.

Department of Historical Sciences

Greek Catholic Theological Faculty

The University of Presov in Presov

Ul. Biskupa Gojdica 2

08001 Presov

Slovak Republic

valcovci@gmail.com

Prof. Aydar M. Kalimullin, Doctor of History,

Director of the Institute of Psychology and Education

Kazan (Volga region) Federal University

18 Kremlyovskaya Str.

420008 Kazan

Russia

kalimullin@yandex.ru

Prof. Alexander A. Galushkin, $\mathrm{PhD}$

Department of Municipal Law

Peoples' Friendship University of Russia (RUDN University)

Miklukho-Maklaya Str. 6

117198, Moscow

Russia

Laboratory of Macroeconomic Regulation and Planning

Stolypin International Institute of Informatization and Public Administration

11/2 Malaya Semyonovskaya Str.

107023, Moscow

Russia

alexander.galushkin@yandex.ru 